\title{
Hypertrophy of the Islets of Langerhans of Frog Tadpoles after Partial Pancreatectomy ${ }^{1}$
}

\author{
B. E. FRYE \\ Department of Zoology, University of Michigan, \\ Ann Arbor, Michigan
}

\begin{abstract}
Subsequent to incomplete surgical removal of the dorsal pancreatic rudiment of Rana pipiens embryos, islets of Langerhans arise in the pancreas, but in smaller amount than normal. Conpensatory hypertrophy of the beta cells occurs, and the islets are transformed from a larval into an adult histological type. Larval growth and metamorphosis is otherwise unaffected. The evidence supports the hypothesis that metamorphic maturation of the islets of Langerhans is a consequence of an increase in the functional demand on the islets of the frog as compared to the tadpole, and not to direct metamorphic effects of thyroxine. Possible causes for a relatively higher insulin requirement of the frog include (1) an increase in the carbohydrate load on the islets, (2) an increase in the secretion of hyperglycemic hormones, and (3) a higher rate of insulin inactivation.
\end{abstract}

The islets of Langerhans of amphibians undergo transformation from a larval to an adult type during metamorphosis. The nature of some of these changes has been mentioned previously (Frye, '58, '64) and has been interpreted as evidence for functional maturation at metamorphosis. Recently, experimental evidence has been published in support of this view (Frye, '64). Two possible hypotheses can be stated regarding the cause of the maturational changes which occur during metamorphosis. (1) The change could occur as a direct action of thyroxine upon the islets, just as many other metamorphic changes have been shown to be primary responses to increasing thyroxine levels (e.g., Kaltenbach, '53). (2) Alternatively, the islet maturation could be a secondary effect of other metamorphic events, i.e., alterations in carbohydrate metabolism which result in an increase in the "functional demand" (insulin requirement) made on the beta cells. The observations reported in this paper support the second view. In addition, data are presented on the development of partially depancreatized larvae.

The experiments reported here were originally done for a different purpose, namely, to test the observation that islet tissue is limited in origin to the dorsal pancreatic rudiment (Frye, '62). Islets were present, however, in the pancreases of all specimens from which the dorsal pancreatic rudiment had been removed. This result can probably be explained as due to incomplete removal of the dorsal rudiment and/or its partial regeneration. Since this possibility has not been checked, I do not regard the experiments as conclusive on the question of the embryonic derivation of the islets. The important point in the present report is the fact that, although islets were present in the experimental animals, they were greatly reduced in amount and showed a fairly marked degree of beta cell and islet hypertrophy.

\section{MATERIALS AND METHODS}

Adult Rana pipiens were obtained from a New York supplier. Ovulation was induced and the eggs expressed and inseminated according to the method of Rugh ('48). The embryos were kept in aged tap water until they reached stage 22 of Shumway (Rugh, '48). Surgery was performed at stage 22 in Holtfreter's solution and under MS 222 anesthesia (strength about 1:3000). An incision through the body wall overlying the pyloric region of the foregut was made with iridectomy scissors. The pancreatic rudiment of of choice (there are three: one dorsal, and a right and left ventral) was removed with

1 This investigation was supported by Grant AM05818 from the Public Health Service, and by a grant from the Rackham School of Graduate Studies, University of Michigan. 
fine jeweler's forceps. The embryos were left in dishes of Holtfreter's solution to heal for four days or until they reached approximately stage 25 of the Shumway series. Subsequently they were cultured in fingerbowls of aged tap water. They were fed on Purina Laboratory Chow which had been ground to a coarse powder.

Determination of length and of development stage was made periodically on anesthetized animals with the aid of a microscope at $10 \times$ magnification. A millimeter ruler was placed under the dish and the snout-anus length measured to the nearest millimeter. When the animals were sacrificed they were anesthetized and then blotted and weighed on a 1,000 mg torsion balance (Roller-Smith). A measured blood sample of $0.02-0.08 \mathrm{ml}$ was taken directly from the surgically exposed heart with a fine tipped glass pipette. The pancreas was excised, blotted briefly on filter paper, weighed to the nearest milligram, and fixed in Bouin's fixative. The blood samples were deproteinized in $1 \mathrm{ml}$ of Folin and Wu reagent ('19), and glucose was determined on a $1 / 2 \mathrm{ml}$ aliquot of the supernatant, using $2 \mathrm{ml}$ of Dreywood's anthrone reagent (Morris, '48) per determination. The fixed material was embedded in paraffin, serially sectioned at $10 \mu$, and stained with Heidenhain's azan. Islet cross-sectional area was estimated by projecting every fifth section with a camera lucida to a magnification of $445 \times$ and tracing the outline of all islets on paper. The area of the tracings was measured with a planimeter.

\section{OBSERVATIONS AND RESULTS}

1. Growth and development of partially depancreatized larvae. The immediate post-operative mortality following the re- moval of the pancreatic rudiments was about $25 \%$. After healing was complete and feeding begun, survival was nearly $100 \%$. With the exception of one group, partial pancreatectomy did not affect the rate of larval growth or development (tables 1 and 2). The exceptional group (table 1, exptl. (b)) consisted of animals which on autopsy proved to have no pancreatic tissue whatever. The guts of these animals were full of undigested food, and they produced copious feces of virtually unaltered food. These animals were in effect starved and did not grow or develop much beyond the stage reached at the beginning of the experiment. Quite clearly, however, as long as a digestive function was retained, partial pancreatectomy did not retard or accelerate development. Inas much as islets of Langerhans were present in all cases examined, the data do not permit an answer to the question of a possible role of pancreatic endocrine secretion in larval growth and development. Insulin is an anabolic hormone which has been shown to affect growth (Salter and Best, '53). For this reason its effects on larval growth should be reinvestigated critically.

2. Islets of Langerhans. Islets were present in the pancreas of every specimen which was examined microscopically (table 2). Histological alterations in the islets of partially depancreatized animals (removal of the dorsal pancreatic rudiment presumed to be incomplete in the present experiments; see introduction) were pronounced. The typical larval islet (up to about stage XVIII) consists of small glomerular groups of cuboidal beta cells which are always closely associated with a more-or-less expanded capillary sinusoid. Figures 1 and 2 are representative of the morphology of the larval tissue. The

TABLE 1

Growth and development of dorsally depancreatized larvae

\begin{tabular}{lccccc}
\hline Group & $\begin{array}{c}\text { No. } \\
\text { operated }\end{array}$ & $\begin{array}{c}\text { Initial } \\
\text { length } 1\end{array}$ & \multicolumn{3}{c}{ Length 1 and stage (post-op.) } \\
\cline { 3 - 6 } Control & 34 & 5.3 & $\begin{array}{c}9.3(8.0-10.0) \\
\text { III (III-IV) }\end{array}$ & $\begin{array}{c}14.1(12.5-16.0) \\
\text { V(III-VII) }\end{array}$ & $\begin{array}{c}18.6(17.5-20.0) \\
\text { VII(VI-VIII) }\end{array}$ \\
Exptl. & 41 & 5.3 & (a) $\begin{array}{c}9.2(8.2-10.0) \\
\text { III }(\text { III-IV })\end{array}$ & $\begin{array}{c}13.9(13.3-14.5) \\
\text { V(IV-V })\end{array}$ & $\begin{array}{c}18.7(17.9-20.0) \\
\text { VII (V-IX) }\end{array}$ \\
\hline
\end{tabular}

' Snout-anus length in $\mathrm{mm}$. 
beta cells are small, usually 8-12 $\mu$ in longest dimension, and have small nuclei. By contrast, the islets of partially depancreatized tadpoles consist of large, columnar beta cells, which in the case of the larger islets form long tortuous cords entwined in an extensive capillary bed. The beta cells are distinctly hypertrophic, usually measuring between 12 and $20 \mu$ in height, and they have enlarged nuclei (figs. 3, 4, 5, 6). The histological appearance of these hypertrophic islets is remarkably like that of a normal adult frog (fig. 7).

Two other observations also indicate that compensatory changes have occurred in the islets of the partially depancreatized tadpoles. (1) Whereas the total amount of pancreatic tissue ( $\mathrm{mg} / \mathrm{gm}$ body $\mathrm{wt}$ ) averages approximately $25 \%$ of normal, the islet area $\left(\mathrm{cm}^{2} / \mathrm{gm}\right.$ body wt) for the same specimens averages about $50 \%$ of normal (table 2). Hence there is an increased growth of the islet tissue as compared to the acinar tissue. The result becomes very significant when one considers the fact that the islets arise largely (probably entirely) from the dorsal pancreatic rudiment (Frye, '62), most of which was removed in these animals. (2) The size of the individual islets was determined from the projected tracings. The average projected areas were $1.71 \mathrm{~cm}^{2}$ and 2.34 $\mathrm{cm}^{2}$ for controls and experimentals, respectively.

I have no evidence to indicate to what extent hyperplasia is important in the increase in the islets after partial pancreatectomy, but ample histological evidence is presented above that beta cell hypertrophy is a very significant factor.

Blood glucose levels were in the normal range for all the experimental specimens except number 32 (table 2). This specimen was distinctly hyperglycemic. There was a very small amount of islet tissue in

TABLE 2

\begin{tabular}{|c|c|c|c|c|c|c|c|c|}
\hline Group & No. & Age 1 & Stage ${ }^{2}$ & Length & Body wt & $\underset{\text { wt }}{\text { Pancreas }}$ & $\begin{array}{c}\text { Islet }^{3} \\
\text { area }\end{array}$ & $\underset{\text { glucose }}{\text { Blood }}$ \\
\hline & & & & $m m$ & $m \boldsymbol{g}$ & $m \boldsymbol{g}$ & $\mathrm{sq} \mathrm{cm}$ & $m g \%$ \\
\hline \multirow[t]{12}{*}{ Control } & 7 & 74 & XII & 23 & 781.9 & 2.2 & 111.0 & \\
\hline & 13 & 74 & XII & 20 & 788.2 & 1.7 & 105.2 & 47.5 \\
\hline & 15 & 74 & XIII & 21 & 822.8 & 2.8 & 147.7 & 37.9 \\
\hline & 17 & 74 & XIII & 24 & 816.0 & 2.1 & 126.3 & \\
\hline & 18 & 74 & XIII & 23 & 644.8 & 1.2 & & 37.0 \\
\hline & 1 & 88 & XIV & 22 & 894.6 & 2.9 & 101.8 & 58.1 \\
\hline & 4 & 88 & XV & 22 & & 3.5 & 172.5 & \\
\hline & 10 & 88 & XVII & 22 & 948.7 & 3.6 & 156.6 & \\
\hline & 11 & 88 & & 20 & 909.1 & 3.6 & 139.0 & 37.4 \\
\hline & 27 & 88 & $\mathrm{X}$ & 22 & 702.9 & 3.6 & 110.1 & 56.1 \\
\hline & 36 & 88 & XII & 23 & 860.5 & 3.4 & 96.8 & 56.1 \\
\hline & & & \multicolumn{2}{|c|}{$\begin{array}{r}\text { Average: } \\
\text { Per gram body wt: }\end{array}$} & 817.0 & $\begin{array}{l}2.78 \\
3.40\end{array}$ & $\begin{array}{l}126.7 \\
154.9\end{array}$ & \\
\hline \multirow[t]{13}{*}{ Dorsal depanc. } & 1 & 74 & XIII & 22 & 676.2 & 0.8 & 55.3 & 43.7 \\
\hline & 7 & 74 & XIII & 20 & 591.9 & 0.6 & 45.3 & \\
\hline & 15 & 74 & XII & 23 & 832.0 & & 61.4 & \\
\hline & $2^{4}$ & 88 & XXI & 18 & 564.8 & 0.1 & & 69.7 \\
\hline & $8^{4}$ & 88 & $\mathrm{XX}$ & 18 & 705.4 & 0.2 & & 64.5 \\
\hline & 9 & 88 & XIV & 23 & 984.4 & 0.1 & 58.8 & 51.6 \\
\hline & 13 & 88 & XIII & 21 & 991.9 & 0.4 & 102.7 & 56.8 \\
\hline & 14 & 88 & XII & 24 & 856.4 & 1.2 & 53.2 & 42.6 \\
\hline & 18 & 88 & XIII & 24 & 899.1 & 0.8 & 91.0 & 38.7 \\
\hline & 26 & 88 & XII & 23 & 845.5 & 0.7 & 42.0 & 51.6 \\
\hline & 32 & 88 & $\mathbf{x}$ & 21 & 588.7 & 0.4 & 6.6 & 107.4 \\
\hline & 39 & 88 & IX & 22 & 596.4 & 0.9 & 35.8 & 58.1 \\
\hline & & & \multicolumn{2}{|c|}{$\begin{array}{r}\text { Average: } \\
\text { Per gram body wt: }\end{array}$} & 760.9 & $\begin{array}{l}0.56 \\
0.74\end{array}$ & $\begin{array}{l}55.2 \\
72.5\end{array}$ & \\
\hline
\end{tabular}

1 Age in days post-operative.

2 Taylor and Kollros stages (see Rugh,'48).

3 Projected area, to a magnification of approximately $445 \times$.

4 These two specimens omitted from histological analysis. 
this specimen, and the beta cells showed changes (fig. 5) typical of glandular exhaustion.

\section{DISCUSSION}

The hypothesis supported in this paper is the following: maturational changes which occur in the islets of Langerhans of amphibians at metamorphosis are a secondary consequence of other metabolic changes which occur at this time. Metabolic alterations lead to an increase in the functional load on the islets. Hypertrophic or compensatory changes are thereby induced in the beta cells, commensurate with the greater insulin demand. This hypothesis has two corollaries: (1) it precludes a direct action of thyroxine upon the islets of Langerhans as the primary cause of the differentiative changes in the islets at metamorphosis (but it does not rule out a possible "permissive" role of thyroxine); (2) it suggests that the observed morphological and histochemical changes in the islets of Langerhans reflect an increase in the magnitude of secretory activity rather than qualitative changes in functional differentiation.

If this hypothesis is correct, one should be able to mimic the maturational changes of the islets during metamorphosis by any experimental treatment which creates a relative insulin deficiency in the animal and thus an increase in the secretory activity of the islets (provided, of course, that the treatment is severe enough to evoke discernible changes). Hypertrophic and/or compensatory changes can be induced in the islets of mammals in many ways: a chronic glucose load (see Frye, '57), subtotal pancreatectomy (Langfeldt, '20), and injection of hyperglycemic hormones (e.g., Volk and Lazarus, '59; Haist et al., "49). Although extensive experiments of this nature have not been done with amphibians, it is probable that the secretory control of the amphibian pancreatic beta cell is similar to that of mammals. Wurster and Miller ('60) have induced hypertrophic and exhaustive changes by means of both glucose and cortisone injections; Houssay and coworkers report insulin antagonistic effects of anterior pituitary hormones in amphibians (Houssay, '59).
My major argument is, therefore, that the hypertrophic changes described in the islets of partially depancreatized tadpoles are of a "compensatory" nature and reflect a higher functional activity per beta cell than exists in the normal tadpole. By the simple expedient of reducing the amount of pancreatic islet tissue, cellular and morphological changes like those which occur during metamorphosis have been induced. Hence the hypothesis is supported. It is clear that if the metamorphic changes in the islets were caused directly by an increase in thyroid activity one could not induce the precocious changes noted without also inducing precocious metamorphosis.

In every specimen except one, adequate functional compensation seems to have been achieved, since the blood glucose levels are in the normal range. (It has previously been shown for $R$. clamitans that total pancreatectomy during the midmetamorphic period results in hyperglycemia (Frye, '64).) One specimen was distinctly hyperglycemic, however, and this correlates with the fact that this specimen contained only four small islets, amounting to less than $10 \%$ of the normal area. These islets showed distinct exhaustive changes, notably hypertrophy with vacuolation. In the rat $5 \%$ or more of the pancreas is required to prevent diabetes following subtotal pancreatectomy, provided the animal is unchallenged otherwise (Houssay, '59).

If the transformation of the islets from a larval to an adult type is to be regarded as a "functional hypertrophy," one must ask what the basis is for the increased insulin requirement, or relative insulin deficiency, in the adult. Three possibilities will be discussed here: (1) An increase in carbohydrate load. It has been shown in two species (R. clamitans, Frye, '64, and Ambystoma tigrinum, Frye, Smith and Frasier, unpublished) that there is a rise in blood sugar levels from larval to adult values during metamorphosis. A moderate increase in glucose load need not, however, be reflected by an actual increase in blood glucose in all species in order to achieve the same effect; i.e., the tendency to hyperglycemia might be effectively countered by the increase in insulin 
secretion. The importance of the hyperglycemia observed in the cases cited is that it provides direct evidence for an increase in the functional stress on the islets, which might otherwise be difficult to show objectively. (2) An increase in the secretion of insulin antagonistic hormones. Adrenal corticoids are hyperglycemic in amphibians (Wurster and Miller, '60), and the adrenal cortex has been reported to become functional during metamorphosis (Rapola, '63). The same might be true for some pituitary hormones which are also insulin antagonistic. (3) An increase in insulin inactivating activity of the liver. Although insulin-inactivating activity has been shown for the adult bullfrog liver (Weisenfeld et al., '58), there is no evi-dence that such activity is present, or at a level different from the adult, in the larval liver. Since the islets secrete into the hepatic portal drainage, it is clear that a rise in the rate of insulin inactivation would create a relative insulin deficiency and hence have the same effect on the islets as an absolute increase in carbohydrate load or a rise in insulin-antagonistic hormones.

\section{LITERATURE CITED}

Folin, O., and H. Wu 1919 A system of blood analysis. J. Biol. Chem., 38: 81-110.

Frye, B. E. 1957 The differentiation of the endocrine pancreas in fetuses of alloxan diabetic and insulin-treated rats. J. Morph., 101: 325-358.

1958 Development of the pancreas in Ambystoma opacum. Am. J. Anat., 102: 117140.
1962 Extirpation and transplantation of the pancreatic rudiments of the salamanders Ambystoma punctatum and Eurycea bislineata. Anat. Rec., 144: 97-107.

- 1964 Metamorphic changes in the blood sugar and the pancreatic islets of the frog, Rana clamitans. J. Exp. Zool., 155: 215224.

Haist, R. E., M. Evans, B. Kinash, E. E. Bryans and M. A. Ashworth 1949 Factors affecting the volume of the islands of Langerhans. Proc. Am. Diabetes Assoc., 9: 53-62.

Houssay, B. A. 1959 Comparative physiology of the endocrine panceras. In: Symposium on Comparative Endocrinolgy, ed. by A. Gorbman. Wiley, New York, pp. 639-667.

Kaltenbach, J. C. 1953 Local action of thyroxine on amphibian metamorphosis. I. Local metamorphosis in Rana pipiens larvae effected by thyroxine-cholesterol implants. J. Exp. Zool., 122: 21-39.

Langfeldt, E. 1920 The partial pancreatectomy. Investigations regarding experimental chronic pancreatic diabetes. Acta Med. Scandinav., 53: 1-191.

Morris, D. L. 1948 Quantitative determination of carbohydrates with Dreywood's anthrone reagent. Science, 107: 254-255.

Rapola, J. 1963 The adrenal cortex and metamorphosis of Xenopus laevis Dandin. Gen. and Comp. Endocrinol., 3: 412-421.

Rugh, R. 1948 Experimental Embryology. Burgess Publishing Co., Minneapolis, pp. 102-113.

Salter, J., and C. H. Best 1953 Insulin as a growth hormone. Brit. Med. Jour., 353-356.

Volk, B. W., and S.. S. Lazarus 1959 Effect of adrenalin on blood glucose and pancreatic morphology. Endocrinol., 65: 586-593.

Weisenfeld, S., R. H. Jauregui and M. G. Goldner 1958 Inactivation of insulin by the isolated liver of the bullfrog. Am. J. Physiol., 188: 45-48.

Wurster, D. H., and M. R. Miller 1960 Studies on the blood glucose and pancreatic islets of the salamander, Taricha torosa. Comp. Biochem. Physiol., 1: 101-109. 
PLATE 1

EXPLANATION OF FIGURES

All Igures are magnified approximately $540 \times$. The islets lie between the arrows.

1 and 2 Normal larval islets of stage XIII.

3, 4 and 6 Islets of partially depancreatized tadpoles of stage XIII. The beta cells are columnar and the cells and the nuclei are hyper. trophic as compared to the normal larval condition.

5 Islet of a partially depancreatized larva which was hypergly. cemic (no. 32). Vacuolative damage ( $v$ ) can be seen in sev. eral cells.

7 Normal adult frog islet. 


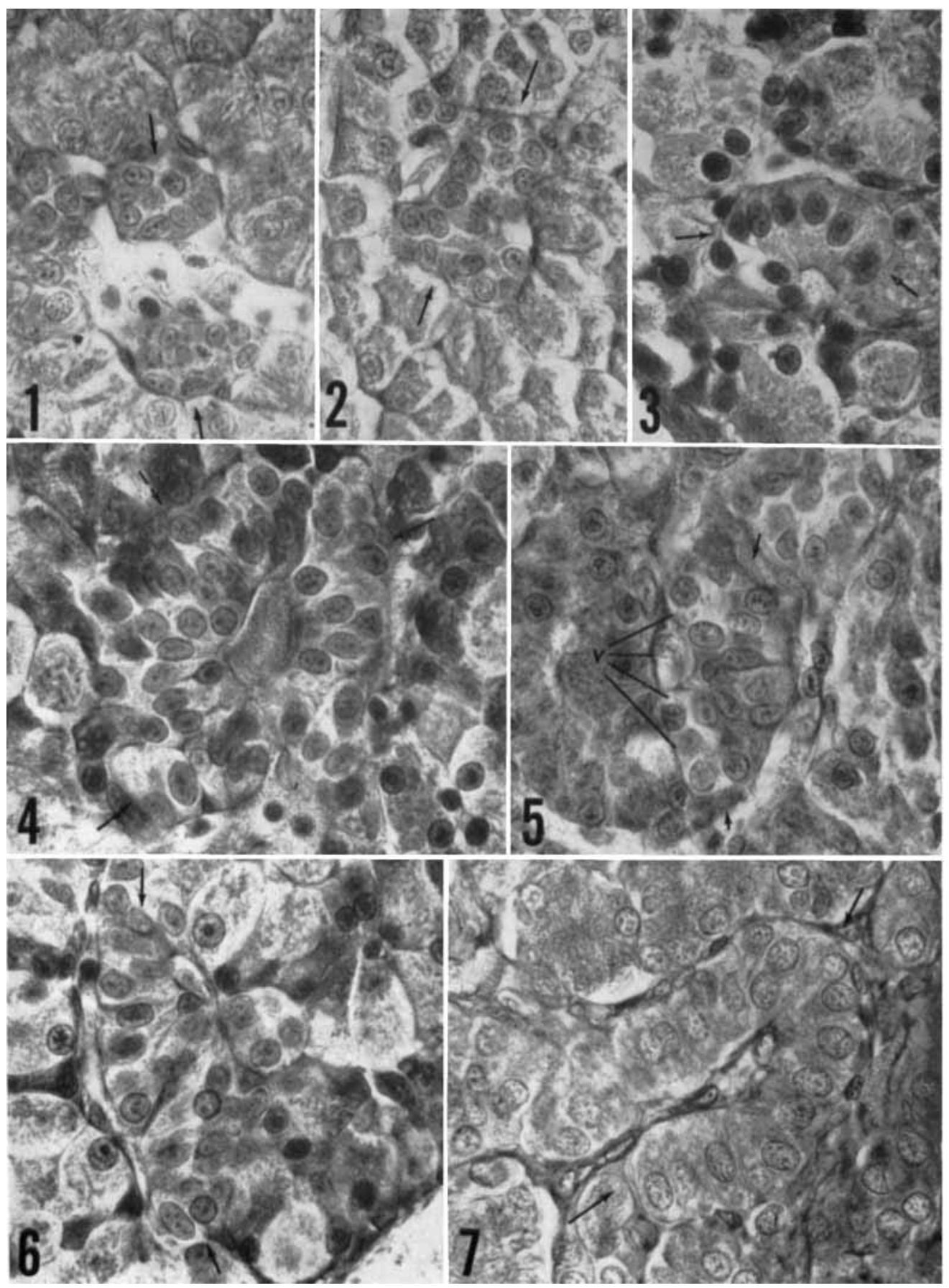

